\title{
一枚型イオンスパッタ金属膜によるき裂長さの測定*
}

\author{
鄧鋼*1, 奈須 光太郎*2 \\ 黒 岩修 平*2, 中西? 勉*1
}

\section{Crack Length Measurement with an Ion Sputtered Metal Film}

\author{
Gang DENG*3, Koutarou NASU, \\ Syuuhei KUROIWA and Tsutomu NAKANISHI \\ ${ }^{* 3}$ Department of Mechanical Systems Engineering, University of Miyazaki, \\ 1-1 Gakuen Kibanadai Nishi, Miyazaki-shi, Miyazaki, 889-2192 Japan
}

\begin{abstract}
This research developed a simple and high precision method to measure the length of a fatigue crack using an extremely thin ion sputtered metal film based on that the electric resistance of the film changes with the increase of the crack. The electric resistance of a cracked film was calculated by the electrothermal FEM analysis. Based on the FEM analysis results, the relationship between the electric resistance and crack length is expressed by a practical formula. Fatigue crack length measurements for acrylic and metal test specimens were performed on the three-points fatigue test equipment. Based on the good agreements between the measurement results by the ion sputtered film and that by the optical microscope, it is clarified that the crack length measurement method with an ion sputtered metal film has a very high precision. In addition that the measurement system is very simple, this method can be said to have a high practical usability.
\end{abstract}

Key Words: Crack Length Measurement, Thin Film, Ion Sputtered Film, Micro-Crack, Fatigue Crack Detection

\section{1. 緒言}

歯車や軸などの動力を伝える機械要素の疲労破損 においては, き裂の発生とその後の短いき裂の進展時 間は疲労過程のほとんどを占めていることが知られ (1) (3), き裂の発生の検知と短いき裂の進展特徵の解 明は疲労寿命推定にとってきわめて重要な課題である. したがって, 動力伝達用機械要素におけるき裂の進展 特徵の解明には疲労き裂長さ, 特に短いき裂の長さを 測定する技術が必要である。このき裂長さの測定には, これまでにき裂の進展にともなう試験片の変位, 剛性, コンプライアンスまたは電気的変化を通してき裂長さ を推定する方法 ${ }^{(4)}$ ( ${ }^{(10)}$, 光学顕微鏡や光学グリッド技 術を用いてき裂の長さを測定する方法 ${ }^{(11)}$ (13), およ び,アコースティックエミッション法 ${ }^{(14)}$ と超音波法 ${ }^{(15)}$ がある。しかしながら，それらの測定方法は，測定シ ステムにおいて特殊な計測機器が必要であること, 測

* 原稿受付 2006 年 9 月 19 日.

*1 正員, 宮崎大学工学部( -889 -2192 宮崎市学園木花台西 11).

*2 ヤマザキマザック (株) (恶 480-0197 愛知県丹羽郡大口町乗 船 1).

E-mail : t0d114u@cc.miyazaki-u.ac.jp
定值とき裂長さとの関係の煩雑さ，き裂長さの測定と 記録の連続性等の面から実際の歯車など機械要素のき 裂の測定，特に $1 \mathrm{~mm}$ 以下の短いき裂長さおよび遅い き裂進展速度の測定への応用は困難であると思われる. 一方, 著者らはき裂を含む薄い金属膜の電気抵抗と き裂長さとの関係に基づき，グリッド型イオンスパッ タリング金属膜を用いて非金属材の疲労き裂長さの測 定技術を開発してきた ${ }^{(16)}$. その測定法に用いられた 金属膜の厚さはわずか数ナノメーターであるため, 膜 のき裂先端は被測面のき裂先端と完全に一致している と思われ，き裂長さの測定精度は高く，光学顥微鏡と ほぼ同等である.しかしながら，グリッド型イオンス パッタリング金属膜を微小き裂長さの測定に用いる場 合, グリッドのピッチを極力小さくすることが必要で あり，また，この測定法を金属試験片に用いた場合， 試験片と金属膜との間に絶縁膜が必要であり,これま でと同様に一枚のスパッタ金属膜をハイトゲージによ る引っかき方法によるグリッドの加工では，絶縁膜を 破損せずに精細なグリッド膜の作成は困難である.し たがって，微小き裂長さの测定や金属試験片への適用 


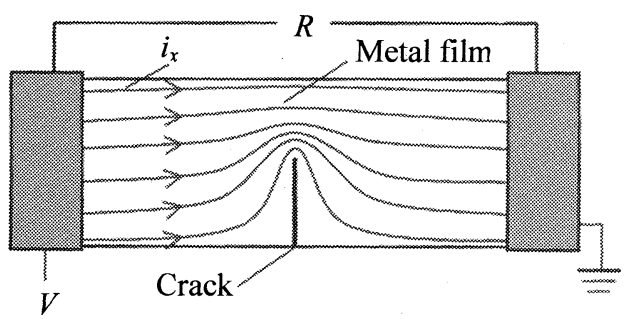

Fig. 1 Electron flow in a cracked metal film

と利便性を考えれば，一枚型のイオンスパッタリング 金属膜の使用が望まれる. そこで，本研究では，一枚 型イオンスパッタ金属膜による金属試験片の疲労き裂 長さの測定技術の確立を目的として，まず，イオンス パッタ金属膜の電気抵抗とき裂長さとの関係を有限要 素法の解析で調べ, 次に, その関係を用いて三点曲げ 疲労試験片のき裂長さの測定を行い，き裂長さの測定 方法の実用性と测定精度について検討した.

\section{2. き裂を含む金属膜の電気抵抗}

通常, 導体の電気抵抗は物体の断面寸法と長さおよ び材料の電気抵抗率から求められる. しかし, き裂を 含む一枚型金属膜の電気力線は図 1 に示すようにき裂 先端を迁回するため, その場合の電気抵抗を理論式を 用いて推定することは困難である.

小川らはセラミックスなどの絶縁脆性材料のき裂長 さを測定するため, 炭素薄膜を用いた方法について研 究を行い, 有限要素法の解析結果に基づき炭素薄膜の 電気抵抗とき裂長さの関係を示す近似式を提案してい $る^{(18)(19)}$. しかしながら, その近似式の適用範囲はき 裂長さが膜の幅の 0.2 倍から 0.8 倍までの間であり， 膜の幅の 0.2 倍以下である短いき裂には適用できない. また, 膜の形状についても膜の長さとき裂進展方向の 膜の幅との比は 0.5 以内との制限があるため, き裂の 進展方向に細長い形の膜が必要であり, 試験片の形状 によってはその形の膜の作成は困難である場合もある. 本研究では短いき裂の測定を目的としているため, 金 属膜のき裂長さは 0 から数ミリまでの間における膜 の電気抵抗とき裂長さとの関係を求める方法が必要で ある。

\section{3. き裂を含む金属膜の電気抵抗の推定}

$3 \cdot 1$ 有限要素法による金属膜の電気抵抗の解析 き裂を含む金属膜に電流を流した場合, 電気力線は 図 1 に示すようき裂先端を迂回するような状況であ り, 電気抵抗を求めるために有限要素法解析を用いる

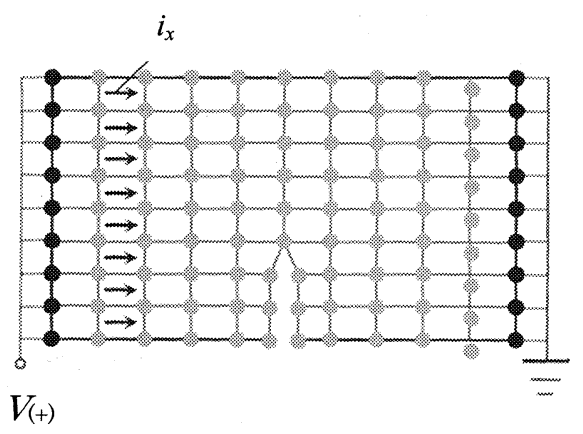

Fig. 2 Mesh and boundary conditions for a metal film electrothermal FEM analysis

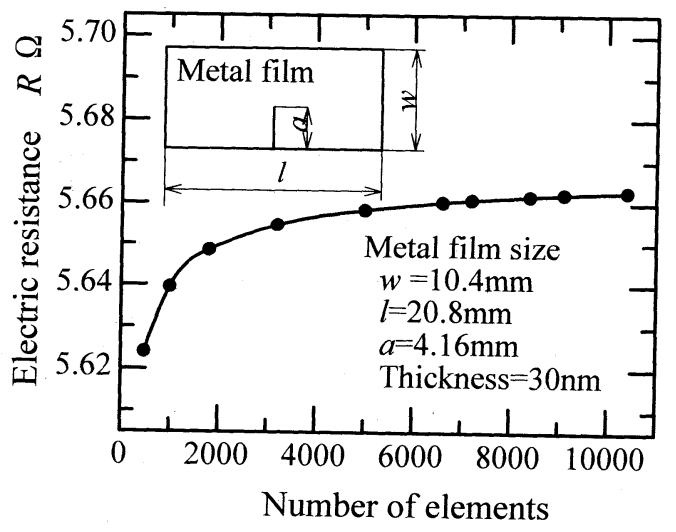

Fig. 3 Electric resistance calculated with different number of elements

ことにした．具体的には図 2 に示す金属膜の要素分割 を用い, 膜の左右に電位差を与えて, 各要素の電流密 度を求め, 膜の断面を通過する総電流はその断面上の 各要素の電流密度と要素の断面積との積を積分して求 められる．膜の電気抵抗はオ一ムの法則より膜両端の 電位差と電流との比で算出できる.

本研究では, 有限要素解析ソフトANSYS の電熱解 析を用いて膜の電気抵抗を求めた．有限要素法の解 析精度は要素の分割によって変わり, 電気抵抗を求め るのに適正な要素数を調べるため，図 2 に示す形状 の金属膜において異なる要素数で電気抵抗を求めた. その結果を図 3 に示す. 長さ $l$ が $20.8 \mathrm{~mm}$ ，幅 $w$ が $10.4 \mathrm{~mm}$ ，き裂長さ $a$ が $4.16 \mathrm{~mm}(a / w=0.4)$ である金 属膜の場合, 要素数 $500 \sim 4000$ において電気抵抗が要 素数の增加にともなって上昇し, 要素数 5000 以上に おいて電気抵抗が一定值に接近していることから，解 析の精度と計算システムの制限を考慮して, 本研究で は, 要素数 6000 程度にして膜の電気抵抗を求めるこ とにした。 


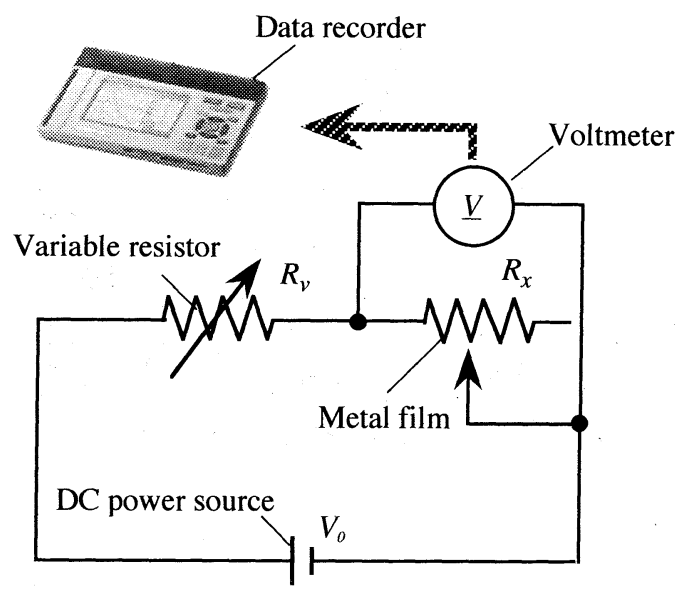

Fig. 4 Electric resistance measurement and recording system for the metal film

$3 \cdot 2$ 金属膜の電気抵抗とき裂長さとの関係 金 属膜の電気抵抗の測定には図 4 に示す直流電源, 可変 抵抗, データーレコーダで構成する簡単なシステムを 用いて行った. 電気抵抗の測定值には微小な配線の抵 抗が含まれると思われ，有限要素法で求めた金属膜の 電気抵抗と電気抵抗の測定值との一致を確認するため に,アクリル試験片の上に作成したイオンスパッタ金 属膜の電気抵抗をカッターで切欠きを導入しながら測 定した. 電気抵抗は膜両端の電位差と直流電源の電圧 および可変抵抗の值から求められ，金属膜の発熱を抑 えるため, 可変抵抗と直流電源の電圧は金属膜に流れ る電流を $100 \mathrm{~mA}$ 以下となるように調整した. 一方, 切久き長さは光学工具顕微鏡を用いて測定した.

異なる切欠き長さにおける金属膜の電気抵抗の測定 值と有限要素法の解析值との比較を図 5 に示す. 切欠 きが長くなるにつれ金属膜の電気抵抗が上昇し，測定 範囲内において测定值と有限要素法の解析值との差は 最大で $2 \sim 3 \%$ であり，有限要素法の解析求めた金属膜 の電気抵抗は電気抵抗の測定值と一致していることが 確認された.

3.3 金属膜の電気抵抗の推定式き裂を含む金 属膜の電気抵抗は有限要素法の解析で推定できる.し かし，簡便性や実用性を考慮すれば，有限要素法の解 析結果に基づいて膜の電気抵抗を計算できる簡単な近 似式が望ましい. 小川ら ${ }^{(18)}$ は炭素膜の電気抵抗の推 定式を提案している. その推定式はき裂長さが膜の幅 の $0.2 \sim 0.8$ 倍の範囲内に限って用いられ，短いき裂の 場合一の適用ができない。一方，図 5 に示す金属膜の 電気抵抗とき裂長さとの関係を一つの簡単な式で表す ことは極めて困難と考えられる.

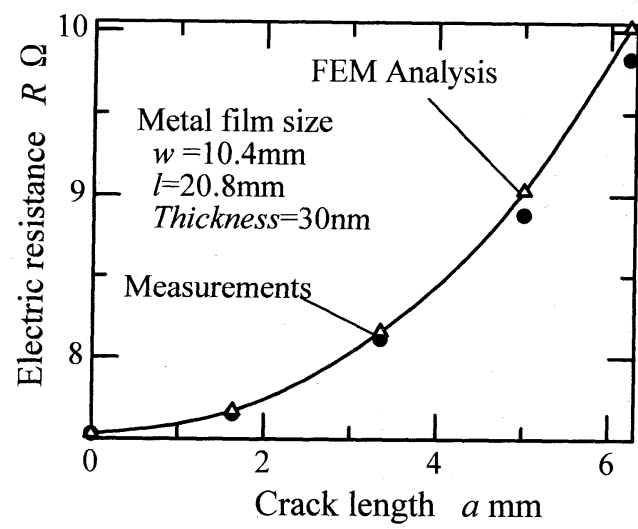

Fig. 5 Calculated and measured electric resistance of a metal film

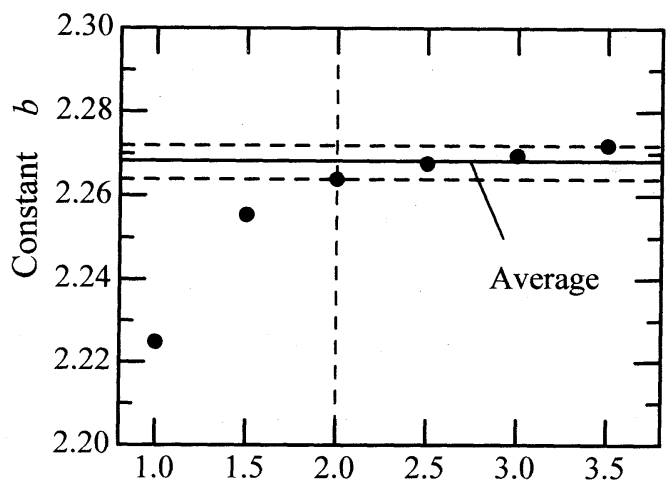

Length-width ratio of the metal film $l / w$

Fig. 6 Factor $b$ for different forms of metal films

本研究では, き裂長さが 0 から膜幅のある割合まで について, 膜の電気抵抗とき裂長さとの関係を以下の 式で示すことを提案した.

$$
R=R_{0}+c a^{b} \quad\left(0 \leqq a \leqq a_{e}\right)
$$

ここで $R$ は長さ $a$ のき裂を有する金属膜の電気抵抗, $R_{0}$ はき裂長さ $a=0$ のときの膜の電気抵抗, $c$ と $b$ は 定数である. $b$ は膜の電気抵抗とき裂長さとの関係曲 線の形を決めるファクターであると考え, 膜の長さ $l$ と幅 $w$ の比 $l / w$ を変えて有限要素法の解析で求めた 膜の電気抵抗とき裂長さとの関係を式 (1) で最小二乗 法で近似して求めた. 得られた定数 $b$ を図 6 に示す. 定数 $b$ 膜の長さと幅の比 $l / w$ が 2 以下において大幅 に上昇している.しかし， $l / w$ が $2 \sim 3.5$ との間におい て定数 $b$ の増加は小さくなっているため, 定数 $b$ をそ の間の平均值 2.268 とした.

一方, イオンスパッタ法で金属膜を作成するため, 


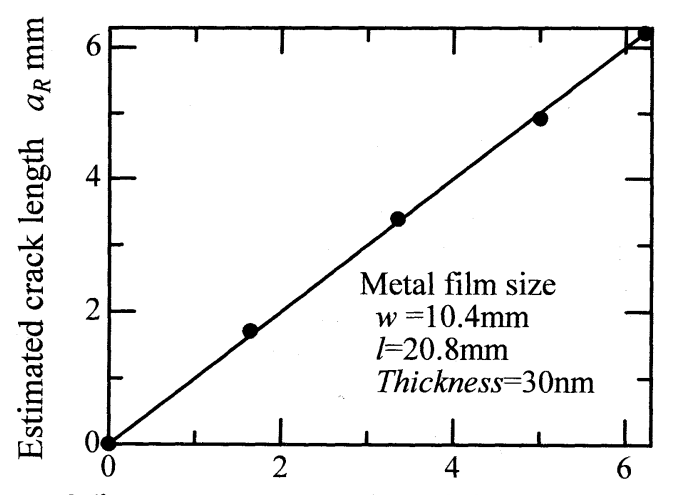

Microscope measured crack length $a_{m} \mathrm{~mm}$

Fig. 7 Accuracy of crack length estimation from the electric resistance of the metal film

所定厚さの膜の作成が困難であり, また, 金属膜の電 気抵抗率も通常の金属膜の材質の電気抵抗率之異なっ ている. そのため, 膜が一定の長さと幅の場合でも, 金属膜の電気抵抗が異なる。したがって, 式 (1)の定 数 $c$ は個々の金属膜の膜厚による電気抵抗の違いを考 慮した定数であり, 膜毎に決める必要がある.そこで, き裂が金属膜を完全に切断する前に測定を終了し，そ のとき膜の電気抵抗 $R_{e}$ と顕微鏡などの測定方法で測 定したき裂長さ $a_{e}$ を式 (1) に代入すれば定数 $c$ を決 めることができる，ところで, 式 (1) は金属膜の電気 抵抗とき裂長さとの関係を所定の領域，すなわち，き 裂長さが 0 から $a_{e}$ までの間において近似したもので あり, 電気抵抗の推定值の精度は式の適用範囲に左右 される. そのため, き裂長さ測定終了時のき裂長さ $a_{e}$ によって膜の抵抗值の推定誤差が異なり， $a_{e}$ が長くな るほど推定值の誤差が大きくなると思われる.これま で,アクリル試験片の上にイオンスパッタ金属膜を作 成し，金属膜をカッターで切欠きを導入しながら光学 顕微鏡による切欠き長さの測定と, 図 4 に示す方法で 測定した金属膜の電気抵抗を式 (1) に代入してき裂長 さの推定を行った. そのとき, 式 (1) の定数 $c$ を決め るための切欠きの長さを膜幅の約 0.6 倍にした. 図 7 には式 (1)を用いて膜の電気抵抗から推定したき裂長 さと光学顕微鏡で測定した切欠きの長さとの比較の一 例を示す. 図 7 から両者の一致が確認され，金属膜の 電気抵抗とき裂長さとの関係をを以下の式で近似的に 推定できることがわかった.

$$
\begin{aligned}
R= & R_{0}+c a^{2.268} \\
& (0 \leqq a \leqq 0.6 w, 2.0 \leqq l / w \leqq 3.5)
\end{aligned}
$$

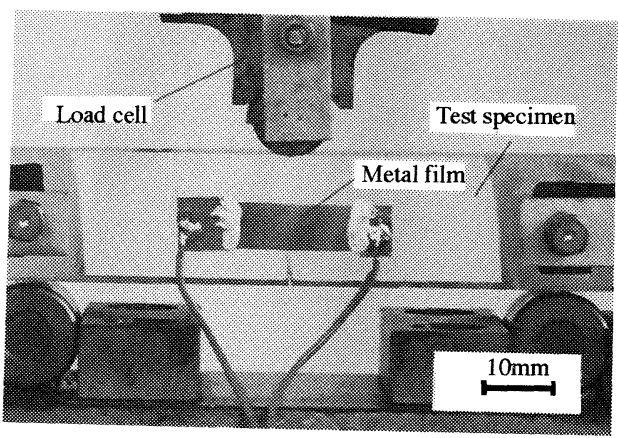

Fig. 8 Three-points bending test rig and acrylic test specimen

なお，式 (2) は簡便性と実用性を考慮して, 有限要 素法の解析の結果を単純にカーブフィッティングした 近似式であり，金属膜の物理的意味を考慮して提案し た式ではない，そのため, 式 (2) は本研究で調べた条 件に限定して有効であると考える.

\section{4. 三点曲げ疲労実験におけるき裂長さの測定}

一枚型イオンスパッタリング金属膜によるき裂長さ 測定法を確かめるため, アクリル製試験片三点曲げ疲 労実験において, 試験片のき裂長さを金属膜と光学顕 微鏡を用いて測定し，一枚型金属膜によるき裂長さの 測定精度を検討した。さらに，本き裂測定法を金属製 試験片に用いる可能性を検討するため, 中炭素鋼製の 試験片の表面に絶縁膜を作成して，三点曲げ疲労実験 においてき裂長さの測定を行い，測定精度を調べた。

\section{$4 \cdot 1$ アクリル試験片の疲労き裂長さの測定 ア} クリル製三点曲げ試験片の長さは $100 \mathrm{~mm}$ ，厚さは $10 \mathrm{~mm}$ ，幅は $20 \mathrm{~mm}$ であり，き裂が発生しやすいよう に試験片の中心部に V 字型の切欠きを入れた. 次に, 試験片側面において切欠き先端近傍にイオンスパッタ 金属 $(\mathrm{Au})$ 膜を作成した。金属膜の長さは $16.7 \mathrm{~mm}$, 幅は $7.0 \mathrm{~mm}$ ，厚さは約 $30 \mathrm{~nm}$ である。

三点曲げ試験片と金属膜および負荷方法を図 8 に示 す. 疲労き裂長さ測定実験は試験片の切欠き部にき裂 を発生させてから行い, 試験片に加えた絽返し荷重は 周波数 $10 \mathrm{~Hz}$ の正弦波であり, 最大荷重が $100 \sim 120 \mathrm{~N}$, 最小荷重と最大荷重の比（荷重比）が約 0.02 である. なお，金属膜の電気抵抗の測定と記録は図 4 に示すシ ステムを用いた.

き裂進展過程において測定は所定の繰返し荷重を加 えた後, 試験片を試験機から取り外して, 光学顕微鏡 によるき裂長さの測定とそのときの金属膜両端の電圧 


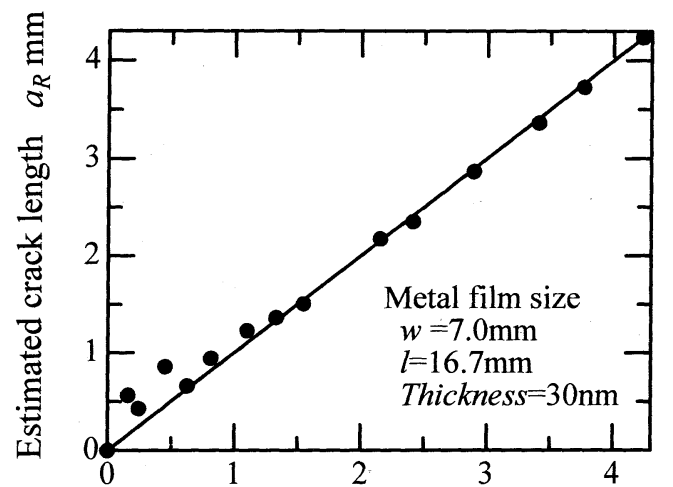

Microscope measured crack length $a_{m} \mathrm{~mm}$

Fig. 9 Crack length measured by a metal film and a microscope for an acrylic specimen

の記録を行った，その後，試験片を試験機に戻して再 び絽返し荷重を加えた．なお，き裂が金属膜の幅の約 0.6 倍の時点で実験を終了し，その時点の金属膜の電 気抵抗 $R_{e}$ と光学顕微鏡で測ったき裂長さ $a_{e}$ を用いて 式 (2) の定数 $c$ を求めた.

アクリル製三点曲げ疲労実験において金属膜の電気 抵抗から推定したき裂長さと光学顕微鏡で測定したき 裂長さの比較を図 9 に示す，図 9 から金属膜によるき裂 長さの測定結果は光学顕微鏡での測定結果と一致して おり，光学顕微鏡で測定したき裂長さを実際のき裂長 さと考えれば，本実験において金属膜によるき裂長さ の測定の最大誤差が $0.113 \mathrm{~mm}$, 平均誤差が $0.051 \mathrm{~mm}$ であり，前報(16) のグリッドタイプのイオンスパッタ 金属膜の測定誤差より大きくなっている. しかしなが ら，0.2mm の測定誤差を有する市販のクラックゲージ での測定法より ${ }^{(17)}$, 一枚型イオンスパッタ金属膜の 測定精度がはるかに高く，また，大きな誤差が生じる 領域はき裂が短い時であり, 試験片の取り外しや実験 を中断したときの計測環境の変化による影響が大きく， 測定を中断せずに金属膜の電気抵抗を連続に記録でき ればより高い測定精度が得られることが考えられる.

4.2 金属製試験片の疲労き裂長さの測定 金属 膜によるき裂長さ測定方法を金属製試験片に用いるた めに, 試験片と金属膜との間に絶縁膜が必要である. 市販のクラックゲージの絶縁にはプラスチックフィル ムが用いられており，その厚さは $10 \sim 20 \mu \mathrm{m}$ であるた め, 試験片表面のき裂先端とクラックゲージのグリッド の切断位置とに差が生じ, き裂の測定誤差は約 $0.2 \mathrm{~mm}$ である(17)，金属膜によるき裂長さ測定は金属製試験 片においてもアクリル製試験片の場合と同等な測定精 度を得るために, 絶縁膜を極力薄くする必要がある.

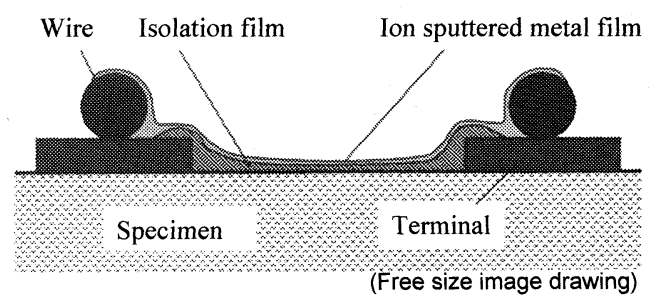

Fig. 10 A sectional image of the insulation film and metal film

したがって，絶縁膜についてはこれまでに，シリコン とフライアッシュガラスの蒸着膜, 酸化塩の塗布, 液 状瞬間接着剤の塗布など様々な方法を試用してきた。 それぞれの絶縁膜の性質や作成の利便性および作成方 法などについてさらに研究を進める予定である.

本研究では, 歯車や軸の疲労強度実験での害用性を 視野にいれ，絶縁膜の作り易さや絶縁の確実さなどの ことを考慮して, 液状瞬間接着剤の塗布を用いて絶縁 膜を作成し，金属膜によるき裂測定法を金属試験片に 用いる可能性について検討した。

き裂長さ測定に用いた中炭素鋼 (S50C) 製の三点曲 げ疲労試験片はアクリル試験片と同じ寸法である. 寒 験では，まず，試験片に高い繰返し荷重を加えて試験 片の切欠き部からき裂を発生させ, その後繰返し荷重 を减少しながらき裂を進展させた。試験片の側面表面 においてき裂を確認してから実験を一時中断し，イオ ンスパッタ金属膜を作成することにした．絶縁膜と金 属膜および配線方法を図 10 に示寸. 配線用のターミ ナルを貼付けてから，絶縁膜の作成，イオンスパッタ 金属膜の作成の手順で行った。なお，き裂進展実験中 の最大荷重は $3000 \mathrm{~N}$ で, 荷重の繰返し速度は $40 \mathrm{~Hz}$ で ある。

絶縁膜の厚さは瞬間接着剤の粘度や塗布速度などに よって異なり, 絶縁膜の厚さによって絶縁抵抗が変わ ると思われる. 本測定に必要な瞬間接着剂絶縁膜の厚 さについては検討中である.これまで作成した絶縁膜 の厚さは平均して $2 \sim 6 \mu \mathrm{m}$ であり, その絶縁膜を用い て金属膜の電気抵抗とき裂長さとの関係を調べた結果, その関係は図 5 に示すアクリル試験片の場合と同じ傾 向にあり，金属膜と試験片との間は絶縁していること が確認された。

中炭素鋼製三点曲げ試験においてイオンスパッタ金 属膜の電気抵抗から式 (2) を用いて推定したき裂長さ と光学顕微鏡で測定したき裂長さの比較を図 11 に示 す, 図 11 からアクリル試験片の場合と同様, 金属膜 


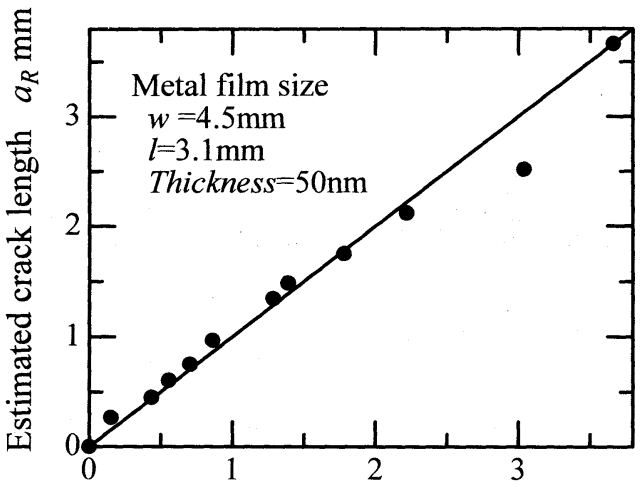

Microscope measured crack length $a_{m} \mathrm{~mm}$

Fig. 11 Crack length measured by a metal film and a microscope for a metal specimen

によるき裂長さの測定結果は光学顕微鏡での測定結果 と一致していることが確認できた。しかしながら, 測 定結果の中で 1 点のみが全体の傾向から大きくはずれ ていることが見られる. その原因は光学顕微鏡でき裂 長さを測定するとき，負荷の解除でき裂の閉口による 金属膜のき裂の局部導通および電気抵抗測定時の配線 の状態などの偶発的要因によるものと思われる.した がって，その点を除外すれば，金属膜によるき裂長さ の測定の最大誤差が $0.113 \mathrm{~mm}$ ，平均誤差が $0.068 \mathrm{~mm}$ である.アクリル試験片と同様に，本測定法は金属製 試験片においてもクラックゲージ法より高い測定精度 を有することが確認され，一枚型イオンスパッタ金属 膜によるき裂長さの測定が金属製試験片にも適用でき ることがわかった，さらに，測定システムの簡便性と 測定精度から，本測定法の高い実用性が明らかである。

\section{5. 結言}

本研究では, 高精度かつ高実用性の疲労き裂長さの 測定技術の開発を目的として，金属製試験片にも適用 可能な一枚型イオンスパッタ金属膜による疲労き裂長 さの測定方法を試みた，具体的には，き裂長さ測定に 必要なき裂長さと金属膜の電気抵抗との関係を有限要 素法の解析を行い，その結果に基づき，電気抵抗の推 定式を提案した．また，三点曲げ疲労実験によるき裂 長さの測定で一枚型イオンスパッ夕金属膜による疲労 き裂長さの測定精度を調べた。得られた主な結果を以 下にまとめる.

(1) 一枚型イオンスパッタ金属膜の電気抵抗とき裂長 さの関係を有限要素法の解析によって明らかにし た. 膜の長さは膜の幅の $2 \sim 3.5$ 倍の長方形膜で,
かつ，き裂長さは膜の幅の $0 \sim 0.6$ 倍の範囲内にお いて，その関係を簡単な式で表せた.

（2）絶縁体のアクリル製三点曲げ試験片においてき裂 長さの測定を行い，一枚型イオンスパッタ金属膜 による測定結果と光学顕微鏡による測定結果との 差が小さく，市販のクラックゲージを用いた測定 方法より高い測定精度を有することが確認された。

（3）金属製三点曲げ試験片において，測定表面とイオ ンスパッタ金属膜との間に瞬間接着剤で絶縁膜を 作成し，絶縁膜の上にイオンスパッタ金属膜を作 成した場合，き裂長さの測定精度はアクリル製試 験片の場合とほぼ同じであり，本測定法の金属製 試験片への利用可能性が確かめられた.

(4) イオンスパッタ金属膜の電気抵抗の測定システム は極めて簡単であり，また，提案式を用いれば電 気抵抗からき裂長さを容易に算出することがで き, 本研究で提案したき裂長さ測定法の高い簡便 性と実用性を示した。

\section{文献}

(1) Deng, G. et al.,Trans. Jpn. Soc. Mech. Eng., Series $C$, Vol.65, No.632 (1999), pp.1649-1654.

(2) Masuyama, T. et al., Trans. Jpn. Soc. Mech. Eng., Series C, Vol.62, No.600 (1996), pp.3289-3295.

(3) Ani Ural et al., Proc. 9th Int. Power Transmission and Gearing Conference, (2003).

(4) Brown,T.F.,Tr. and Srawley,J.E., ASTM STP 410 (1966).

(5) Nisitani, H. and Chen, D., Trans. Jpn. Soc. Mech. Eng., Series A, Vol.51, No.465 (1985), pp.1436-1441.

(6) Kikukawa, M. et al., J. Soc. Materials Science,Jpn. Vol.25, No.276 pp. (1976), 899-903.

(7) Ashida, Y. et al., J. Kansai Soc. N. A., Japan, No.225 (1996), pp.181-185.

(8) Nakai, Y. et al., Trans. Jpn. Soc. Mech. Eng., Series $A$, Vol.55, No.511 (1989), pp.543-548.

(9) Lee, J.H. and Kobayashi, H., Trans. Jpn. Soc. Mech. Eng., Series A, Vol.51, No.461 (1985), pp.142-147.

(10) Jpn. Soc. Mech. Eng., JSME Standard, JSMES001, (1981), pp.8-9.

(11) Bucci, R.J. et al., ASTM STP513, (1972), 125-140.

(12) Mautz, J. and Weiss, V., ASTM STP601, (1976), pp.154-168

(13) James, L.A., ASTM STP738, (1981), pp.45-57.

(14) Masuyama, T. et al., Trans. Jpn. Soc. Mech. Eng., Series C, Vol.60, No.575 (1994), pp.2456-2461.

(15) Shimada, H. and Date, K., Iron and Steel, ISIJ, Vol.60, No.2 (1983), pp.196-202.

(16) Deng, G. et al., Trans. Jpn. Soc. Mech. Eng., Series $C$, Vol.72, No.715 (2006), pp.997-1002.

(17) Deng, G. et al., Trans. Jpn. Soc. Mech. Eng., Series $C$, Vol.57, No.535 (1991), pp.909-913.

(18) T. Ogawa and S. Suresh, Engineering Fracture Mechanics, Vol.39, (1991), No.4, pp.629-640.

(19) Ogawa, T., Trans. Jpn. Soc. Mech. Eng., Series A, Vol.57, No.535 (1991), pp.492-499. 